\title{
LORENZO BARTOLI
}

\author{
"I don't know whether I'm dreaming now, \\ or if I dreamed what I'm about to tell you": \\ FILIPPO BRUNELLESCHI AND THE PERSPECTIVES OF \\ SLEEP IN THE NOVELLA OF THE FAT WOODCARVER
}

A fundamental characteristic of the Florentine figurative tradition at the beginning of the fifteenth century - a characteristic which emerges, for instance, from Filippo Brunelleschi's perspective panels or from Lorenzo Ghiberti's concept of measures of the eye - is that it considers the work of art as a scientific exposition of the master's vision, an exposition which can be confirmed by its principles of measurability and hence by its implicitly collective value. An example of this is the introduction to the vernacular version of Leon Battista Alberti's Della pittura (On Painting) (1436). ${ }^{1}$ Here the mathematical premises of the book are announced through its evocation of a group of Florentine artists who were Alberti's contemporaries. The figure of Filippo Brunelleschi, to whom, it should be recalled, Alberti dedicated the vernacular version of his Della pittura, is the nomen agentis of such a generation, and the construction of the dome of the cathedral in Florence is its nomen actionis.

Ma poi che io dal lungo essilio in quale siamo noi Alberti invecchiati, qui fui in questa nostra sopra l'altre ornatissima patria ridutto, compresi in molti ma prima in te, Filippo, e in quel nostro amicissimo Donato scultore e in quegli altri Nencio e Luca e Masaccio, essere a ogni idata cosa ingegno da non posporli a qual si sia stato antiquo e famoso in queste arti.

Chi mai sì duro o sì invido non lodasse Pippo architetto vedendo qui struttura sì grande, erta sopra e' cieli, ampla da coprire con sua ombra tutti e' populi toscani, fatta sanza alcuno aiuto di travamenti o di copia di legname, quale artificio certo, se io ben iudico, come a questi tempi era incredibile potersi, così forse appresso gli antichi fu non saputo né conosciuto? (7)

(Since then, I have been brought back here [to Florence] — from the long exile in which we Alberti have grown old — into this our city, adorned above all others. I have come to understand that in many men, but especially in you, Filippo, and in our close friend Donato the sculp- 
tor and in others like Nencio, Luca and Masaccio, there is a genius for [accomplishing] every praiseworthy thing. For this they should not be slighted in favour of anyone famous in antiquity in these arts. (39)

Who could ever be hard or envious enough to fail to praise Pippo the architect on seeing here such a large structure, rising above the skies, ample to cover with its shadow all the Tuscan people, and constructed without the aid of centering or great quantity of wood? Since this work seems impossible of execution in our time, if I judge rightly, it was probably unknown and unthought of among the ancients.) (40)

In the scientific and civic attitude which characterizes Alberti's treatise on painting and which represents the more general cultural climate of the age, vision also has social implications, in so far as artistic expression is reaffirmed in a new way. It invokes the participation of the observers, their point of view being the ultimate verification of the measurability of the work of art. Artistic expression, in other words, requires an artistic community or a community of art connoisseurs ("gli intendenti"); it requires a collectivity who will know how to deal with the mathematical implications and the measurements expressed in the work of art.

The affirmation of artistic individuality in the Renaissance was achieved, in fact, in the context of the group, within which a few protagonists would emerge and define themselves thanks to both the exceptionality of their artistic experience and also the recognition of the same exceptionality by the other members of the group. ${ }^{2}$ As it is made abundantly clear in the dedication of Alberti's treatise on painting, Filippo Brunelleschi best represented such a situation. His genius elevated him to heights which were inaccessible for most of the members of his circle; but the confirmation of his superiority is nevertheless ineluctably linked to the mathematical verifrability of his architectural constructions. Significantly, Brunelleschi's perspective panels, which played such a major role in the evolution of the science of vision (and not only in art), did not represent just any old object; rather they reproduced the collective space par excellence in the civic consciousness of fifteenth-century Florence, that is, the Baptistry, seen from the Duomo (cathedral), and the Piazza della Signoria. ${ }^{3}$

The role played by Brunelleschi in the context of the cultural development of Florence in the first part of the fifteenth century is illustrated clearly in the extraordinary story known as the Novella del Grasso legnaiuolo (The Tale of the Fat Woodcarver). ${ }^{4}$ The third version of this novella has been attributed to Antonio di Tuccio Manetti by Giuliano Tanturli on the basis of arguments which can be considered definitive. The attribution has 
contributed to making this fifteenth-century text the object of numerous philological studies, particularly because of its peculiar pluriredactional condition. It is significant that, in recent years, two different editions of the novella have been published (one by Antonio Lanza in 1989 and the other by Paolo Procaccioli in 1990). Both present the text in all the three known versions of the story: that is, the so-called vulgate, written in the first half of the fifteenth century; the Palatino MS. 51 text, published by Michele Barbi in 1893 (Florence: Landi) and composed probably between 1470 and 1478; and finally, the version by Manetti, written as the concluding part of his biography of Filippo Brunelleschi in the 1480s. Leaving aside the question of the philological inclination of Italian criticism, it is evident that the textual tradition of the novella demands an analysis of the variants.

The novella tells the story of a beffa (prank) played by Filippo Brunelleschi on the woodcarver Matteo Ammannatini, also known as il Grasso (the fat man). All three versions of the novella insist on the apparent impossibility of carrying out the beffa proposed by Brunelleschi: that is, to convince Grasso that he has become a different person named Matteo. An impossible beffa, but one nevertheless designed and executed thanks to the ingenuity of the plan devised by Brunelleschi. "Ancora che la brigata conoscessi Filippo di grande ingegno ... quello che diceva pareva a tutti impossibile di farlo: a' quali Filippo assegnate sue ragioni e argumenti cauti e sottili, come colui che era a quelli molto atto, con molte parole gli fece capaci questo potersi fare" (589). ("Although the company knew Filippo to be very clever ... what Filippo was proposing seemed impossible to everyone. But Filippo, who was very good at such things, gave them so many clever, subtle reasons and arguments that he succeeded in convincing them that it could be done") (173).

The interest aroused by the novella is due primarily to its display of Brunelleschi's skill at design, which is accompanied by an equal ability to complete the project as a constructed artefact. It is the same sort of fascination which is mentioned in all of the biographical anecdotes told about Brunelleschi's activities as an architect, and in particular in those more directly related to the construction of the dome of the cathedral in Florence, itself considered an impossible feat. The exceptional nature of the fifteenth-century artist, and of Brunelleschi in particular, seems to lie precisely in his ability to force the impossible into the realm of the possible.

For these reasons it is essential, in the construction of the plot of the novella, that the victim should not be unsuspecting: Grasso, in fact, "non era però tanto semplice, che da altri che da sottili uomini fosse stata compresa la sua semplicità, come quella che non teneva in tutto dello sciocco" 
(he was not so simple that any but very perceptive persons would understand his simplemindedness, which was not real stupidity). This is also reflected in the awareness that Grasso demonstrates of the possibility of being the victim of a beffa like Calandrino, the protagonist of various stories in Boccaccio's Decameron: "Ohimé! sarei io mai Calandrino, ch'io sia sì tosto diventato un altro senza essermene avveduto?" (592) ("Woe is me! Am I like Calandrino, turned into someone else so quickly without realizing it?") (176). Grasso, in other words, does not undergo the change of identity passively: he is not a simple spectator nor a Calandrino. Rather, he investigates his culture and his experience, searching for an explanation for what is happening to him and around him. In a significant scene, which takes place in the debtors' prison where he has been taken in place of Matteo, Grasso, convinced by now that he has really become Matteo, finds himself discussing his situation with a judge who happened to be in the same cell. After having explained his case to the judge, he concludes inquisitively with these words: "Messere ... ché so che avete lungamente letto di molte cose e storie d'antichi e di moderni e di uomini che hanno scritto molti avvenimenti: trovasti voi mai simile cosa?" (597) ("My lord ... for I know that you have long read about many things, including stories of ancient and modern men, and men who have recounted many events. Did you ever come across anything like this?") (181). In as much as his vernacular culture proves to be inadequate, Grasso appeals to the judge's classical culture in order to find an explanation for his misadventures. The dynamics of the narrative, therefore, are not limited to the action of the pranksters vis-à-vis their target, as is the case in most novellas of the fourteenth century. Instead, it is very much dependant on the consequences and primarily the psychological consequences that those actions have for the designated victim. These will be even more intriguing in so far as the victim, rather than abandoning himself to the inevitable rationale of the events, tries nevertheless to control and comprehend them.

In the first two versions of the novella, the vulgate and the Palatino text, the story ends rather quickly, once the beffa has reached its conclusion. After managing, in the space of three days, to convince Grasso that he has become Matteo, Filippo Brunelleschi and his companions polish their work by putting in place the last details of the plan for the beffa. First, they give Grasso a potion to make him fall asleep, and this takes place at Matteo's house. Then, they take him to his own house; they put him in bed; go to his workshop and move every tool from its original place; finally they all go back to their own homes to sleep. The next morning Grasso, having regained possession of his identity but incapable of finding a rea- 
sonable explanation for the events of the day before, decides to leave Florence for good and to move to Hungary. This is how the vulgate presents the scene in which Filippo Brunelleschi and his friends take Grasso home from Matteo's house, and put him to bed (I quote from the MS. BNF II.IV. 128, following Rochon's edition of the manuscript, 357):

All'ora ordinata, Filippo giunse con tre compagni, e entrò nella camera dove elli era, e sentendolo forte russare, lo presono e missonlo in una zana con tutti i suoi panni e condussonlo a casa sua, dove non era persona, ché per avventura sua madre non era ancora tornata di villa, e portatolo insino a letto, ve lo missono dentro e puosono i panni suoi dove li soleva porre egli, quando se n'andava a letto.

(At the agreed time Filippo arrived with three friends and, on entering the room where [Grasso] was, and hearing him snore loudly, they picked him up and put him in a hamper along with all his clothes and brought him to his own house, where, as luck would have it, no one was home, since his mother had not yet returned from the country. Carrying him to his bed, they put him in it and placed his clothes where he usually put them when he went to bed.)

The meaning of the operation is, without any doubt, that of giving Grasso back his identity, through an exact adherence to his most personal habits ("puosono i panni suoi dove li soleva porre" "they placed his clothes where he usually put them"). The same is true in the version of the Palatino text (Rochon 370):

All'ora a ciò diputata, giunse Filippo di ser Brunellesco e co' lui Tommaso di Niccolò d'Aringo, Zanobi di Cristofano Magnolino e Poltrone Cavalcanti, e intrarono in camera dove il Grasso dormia, e sentendolo forte dormire, il presono e missono in una zana con tutti i suoi panni, e portarollo a casa sua, ove per ventura la madre non era di villa tornata, e missollo nel suo letto e i suoi panni puosono dove il Grasso porre li soleva, quando si spogliava.

(At the agreed time, Filippo Brunelleschi arrived with Tommaso di Niccolò d'Aringo, Zanobi di Cristofano Magnolino and Poltrone Cavalcanti; they entered the room where Grasso was sleeping and, hearing that he was sound asleep, they picked him up and put him in a hamper along with all his clothes and carried him to his own house where, as luck would have it, his mother had not yet returned from the country. They put him into bed and placed his clothes where he usually put them when he undressed.)

Manetti's version, on the other hand, presents a reading of this scene that is completely different. It is suggested by a detail that reverses the 
meaning of Brunelleschi's plan as it appears in the two older versions:

In su l'ora a ciò diputata tornò Filippo di ser Brunellesco con sei compagni ..., e entrarono nella camera dov'egli era, e sentendolo forte dormire, lo presono e misollo in una zana con tutti e sua panni e portorollo a casa sua, ove per ventura la madre non era ancora tornata di villa; e loro sapevano tutto, che vegghiavano ogni cosa. E misollo nel letto, e puosono e panni sua dov'egli era usato di porgli; ma lui che soleva dormire da capo, lo puosono dappié [emphasis added]. (609)

(Filippo came back at the agreed time with his friends ... On entering the room where Grasso was, and hearing that he was sound asleep, they picked him up, put him in a hamper along with all his clothes, and carried him to his own house, where, as luck would have it, his mother had not yet returned from the country. They knew all this because they were keeping an eye on everything. And they put him into bed, and placed his clothes where he usually put them. But they put his feet where he usually put his head [emphasis added]). (193)

In the version by Manetti, Filippo Brunelleschi intervenes to twist Grasso's perspectives of sleep, opening the path towards the infiltration into Grasso's mind of yet another element of ambiguity, but this time not external to him (his becoming Matteo), but rather internal, in his domestic world.

Upon awakening, Grasso, in the vulgate and Palatino versions, rediscovers his identity precisely by recognizing the elements familiar to him; and his astonishment derives from the conflict between this identity and that which he experienced on the previous days - a conflict which is exemplified by his having gone to bed in Matteo's house and having awakened in his own bed. According to the Palatino manuscript (see Rochon's edition, 370),

El Grasso, alloppiato pel beveraggio preso, dormì tutta la notte senza giammai risentirsi. La mattina in sull'Ave Maria di Santa Maria del Fiore si destoe quasi ad alta mattina, riconosciuto il suono della campana e, aperti gli occhi (e già alcuno spiraglio dava per la camera) e riconosciuto, vide essere in casa sua, e ricordandosi di tutte le passate cose, cominciò avere ammirazione, e massime recatosi a memoria dove la sera s'era coricato, disse : "O Dio, aiutami!"

(Drugged by the potion he had taken, Grasso slept all night without ever waking up. In the morning, awakening to the sound of the Angelus from Santa Maria del Fiore late in the morning, he recognized the sound of the bell and, opening his eyes, saw some chinks of light in the room. Recognizing [it] he saw that he was in his own house and, remembering 
everything that had happened, he was amazed, especially when he recalled the place where he had gone to bed the night before. He said "God, help me.")

In the Manetti version, on the other hand, Grasso's awakening is very different. The elements are apparently the same, but Grasso's mental activity is no longer characterized by a generic state of confusion. It focuses instead much more specifically on the theme of the interchangeable nature of dream and reality:

El Grasso aloppiato del beveraggio, dormì tutta quella notte sanza mai risentirsi. Ma la mattina in su l'avemaria di Santa Maria del Fiore, avendo fatto el beveraggio tutta l'opera sua, déstosi, essendo già buona mattina, riconosciuto la campana ed aperto gli occhi e veduto alcuno spiraglio per la camera, riconobbe sé essere in casa sua, e vennegli una grande allegrezza al cuore subito, parendogli essere ritornato el Grasso ed in signoria d'ogni sua cosa, parendogliele prima avere peggio che in compromesso, e quasi lagrimava per letizia, non cappiendo in sé; ma pure gli dava noia e maravigliavasi essere dappiè deáletto, ché soleva dormire da capo; e ricordandosi delle cose successe, e dove s'era coricato la sera, e dove si trovava allora, entrò subito in una fantasia d'ambiguità, s'egli aveva sognato quello, o se sognava al presente [emphasis added]. (610)

(Drugged by the potion, Grasso slept all night without ever waking up. But next morning, awakening to the sound of the Angelus from Santa Maria del Fiore, when the effects of the potion had worn off and it was already daylight, he recognized the sound of the bell and, opening his eyes, saw some chinks of light in the room and realized that he was in his own house, and his heart was suddenly filled with great joy, for it seemed he had become Grasso again and was master of all his possessions, which he thought might be lost to him. And now he almost wept, he was so beside himself with joy. Yet he was disturbed and amazed to find his head where he usually put his feet in the bed. And remembering the things that had happened, and where he had gone to sleep the night before, and where he was then, he suddenly fell into a reverie of uncertainty about whether he had been dreaming then or was dreaming now [emphasis added].) (193-194)

A novella about the exchange of identities is transformed into a novella about the exchange of reality and fiction. It takes place inside Grasso's mind and is played out on the basis of the confusion between dream and reality. This is Manetti's essential contribution in terms of narrative invention with respect to the tradition of the novella. This contribution affects not only the construction of the beffa but, significantly, the space in which 
it is to take place: from the streets of Florence, we are led inside Grasso's own mind. Indeed, in the conclusion to the novella, Manetti states that "la maggior parte delle cose da ridere erano state, come si dice, nella mente del Grasso" (628) ("most of the funny things had happened, so to speak, in Grasso's mind") (212). This phrase, which is not found in the other versions of the novella, confirms Manetti's particular focus on the psychological dimension of the story. Commenting on this aspect of the novella, Achille Tartaro has observed that the version by Manetti marks "una civiltà, quella umanistica, che proprio nella conoscenza dell'animo umano, della sua varia fenomenologia, aveva riposto tanta parte della propria ragion d'essere" (225) (humanist civilization, one which had placed a great part of its reason for being precisely in the knowledge of human consciousness in its varied phenomenology).

What must be stressed, in any case, is the insistence on the theme of dreams, introduced by Manetti to modify the tradition of the novella. It is an important theme both for its humanistic implications (it seals the beffa about an exchange of identities-by now completed and concluded-of which Grasso's dream becomes a sort of psychological confirmation, arising from the preceding events 5 ); and in terms of its function within the plot of the beffa itself, it too derives originally from Filippo Brunelleschi's mind, which is instrumental in leading Grasso to confuse dream and reality. Although, in fact, Grasso's meditations on dreams begin with the memory of what happened on the previous days, it is nevertheless significant that those meditations are also suggested by a detail; namely, Grasso's position in bed which, in Manetti's version, becomes part of Brunelleschi's overall strategy for the execution of the beffa. For that reason, the differentiating element introduced by Grasso's position ("ma lui che soleva dormire da capo, lo puosono dappié") ("But they put his feet where he usually put his head") is recovered in the scene of the awakening: "ma pure gli dava noia e maravigliavasi essere dappié del letto, ché soleva dormire da capo" ("Yet he was disturbed and amazed to find his head where he usually put his feet in the bed"), where the insistence on the adversative conjunction $(m a \ldots m a)$ (but ... yet) signals precisely the deviating of that element, with respect to the rationale of the domestic objects which, on the contrary, should return Grasso to his own identity, inducing him to fail to distinguish instead between dream and reality.

In short, it is not so extraordinary that Grasso should struggle to distinguish, in his own mind, between dream and reality; but rather that such ambiguity is born out of Brunelleschi's specific project. So much so, that Manetti, when introducing the character of Matteo, in the last part of 
the novella, insists precisely upon terms of dream and reality. "I' non so s'io mi sogno testé, o s'io m'ho sognato quello ch'i vi dirò" (617) ("I don’t know whether I'm dreaming now, or if I dreamed what I'm about to tell you") (201), says Matteo, before recounting that he slept for two days and dreamt of becoming Grasso. Such a narrative strategy requires, for its own logic, that Brunelleschi know exactly what is going through Grasso's mind. He should know about Grasso's uncertainty between dream and realitya knowledge that the architect must have, since it was he who led Grasso's reasoning in that direction. In Manetti's version of the novella, therefore, Brunelleschi is not just the designer of a beffa by which Grasso is made to believe that he has become Matteo: he is also the maker of another beffa, by which Grasso is made to believe that he has dreamt of becoming Matteo.

In Manetti's version of the story, then, the theme of dream acquires a highly significant role. It indicates, with precision, the limits of Grasso's interpretative ability, particularly in comparison with Brunelleschi's ingenuity. Similar to the reference to classical antiquity in the episode with the judge, the appeal to the dream as an interpretative tool proves to be yet another sign of Grasso's intellectual weakness, the product of a pseudo-culture that is refuted by Brunelleschi's (that is Manetti's) precise rationality, which in fact he can use to carry out his plan.

At the heart of the narrative innovations introduced by Manetti to modify the development of the story of Brunelleschi and Grasso, various traditions converge. First of all, it should be noted that, in the classical tradition of writings on art, the appeal to the oneiric dimension as a key to accessing the realm of the artistic imagination is usually accompanied by some caution, or even skepticism. What Pliny writes about Parrhasius in the Historia Naturalis (Natural History) (Book 35, paragraph 71-72), significantly quoted literally by Ghiberti in his Commeniarii, is emblematic of this attitude:

[Parrhasius] fecundus artifex, sed quo nemo insolentius usus sit gloria artis, namque et cognomina usurpavit habrodiaetum se appellando aliisque versibus principem artis et eam ab se consummatam, super omnia Apollinis se radice ortum et Herculem, qui est Lindi, talem a se pictum, qualem saepe in quiete vidisset.

(Parrhasius was a prolific artist, but one who enjoyed the glory of his art with unparalleled arrogance, for he actually adopted certain surnames, calling himself the 'Bon Viveur,' and in some other verses 'Prince of Painters,' who had brought the art to perfection, and above all saying he was sprung from the lineage of Apollo and that his picture of Heracles at 
Lindos presented the hero as he had often appeared to him in his dreams. ${ }^{6}$ )

On the one hand, there is the artist (in this case Parrhasius) who defends his own vision, even if oneiric, precisely because it signals the supremacy of that specific artistic vision, against that of his competitors; on the other, there is the point of view of the historian (Pliny) who seems to be much more doubtful of the ultimate significance of the oneiric experience of the artist, because it is limited to the artist and cannot be extended to the viewers. It should be noted that Pliny says that Parrhasius "usurpavit" (literally 'usurped') his supremacy - that is, it was not granted to him-thus emphasizing the untenability of Parrhasius's point of view; being entirely subjective to the artist himself, it could not be verified.

Furthermore, in the scientific tradition, and particularly in that of optics, sleep was considered to be the realm of insensibility, or the inability to perceive?: to use Michelangelo Buonarroti's poetic expression, sleep is "not to see or hear" ("non vedere, non sentire"). ${ }^{8}$ It is significant that in the whole third section of Ghiberti's Commentarii, dedicated principally to issues of optics, the only reference to sleep happens to be in relation to the eyelid, which recalls Michelangelo's non vedere. ${ }^{\text {? }}$

Finally it will be useful to refer to the tradition which associates sleep with reflection on time. This is a concept derived from the classical and mercantile traditions alike and is linked to the artistic culture of the fifteenth century. Such an association is exemplified by Giannozzo's words in the third book of Leon Battista Alberti's Della famiglia (On the Family):

Io quanto al tempo cerco adoperarlo bene, e studio di perderne mai nulla ... E per non perdere di cosa sì preziosa punto, io pongo in me questa regola: mai mi lascio stare in ozio, fuggo il sonno, né giacio se non vinto dalla stracchezza. ${ }^{10}$

(My plan, therefore, is to make as good use as possible of time, and never to waste any ... And to waste no part of such a precious thing, I have a rule that I always follow: never remain idle, I avoid sleep, and I do not lie down unless overcome by weariness.)

The artistic world is necessarily linked to the civic and mercantile premises that underlie Giannozzo's reasoning. This can be verified, once again, by referring to Ghiberti's Commentarii. The work opens precisely with a reference to sleep and time, by which "colui che solo giustamente è chiamato savio non permette, etiamdio quel tempo c'è dato a requie del corpo, noi el dormiamo tutto." 11 (He who alone is justly considered wise, 
does not allow even the time allotted to us for resting our bodies to be spent completely sleeping.)

Sleep and dreams, therefore, on which Manetti insists in the final part of the novella, converge to underscore Brunelleschi's ingenuity and his intellectual superiority with respect to Grasso. And yet, what characterizes Brunelleschi's attitude in the novella is not so much his denial of an overall validity to the oneiric dimension of artistic creation, that is, that of Pliny's Parrhasius. Rather, his main contribution is to restrict such a dimension within the limits of the scientific tradition of optics. Significantly, in his Vite (Lives of the Artists) Giorgio Vasari wrote the following about Filippo Brunelleschi: "Era Filippo sciolto da le cure familiari e datosi in preda agli studi, non si curava di mangiare e dormire, solo l'intento suo era l'architettura." ("And since Filippo was free from domestic concerns, he abandoned himself to his studies and did not worry about eating or sleeping; his only concern was architecture.") ${ }^{12}$ Art and architecture are study, and hence require time, which is to be taken away from sleep. Fifteenth-century time is that of late nights, as can be seen by the example of Paolo Uccello. His studies on perspective, as Vasari recounts, are the fruit of those precious moments stolen from the resting of the body: "la moglie soleva dire che tutta la notte Paulo stava nello scrittoio per trovare i termini della prospettiva, e mentre ch'ella a dormire lo invitava et egli le diceva: 'O che dolce cosa è questa prospettiva!'” ([His wife] used to declare that Paolo stayed at his desk all night, searching for the vanishing points of perspective, and when she called him to bed, he used to say to her: 'Oh, what a sweet thing this perspective is!'). ${ }^{13}$

\section{Universidad Autónoma de Madrid}

\section{NOTES}

1 "Scrivendo de pictura in questi brevissimi comentari, acciò che 'I nostro dire sia ben chiaro, piglieremo dai matematici quelle cose in prima quale alla nostra matera apartengano; e conosciutole, quanto l'ingegno ci porgerà, esporremo la pittura dai primi principi della natura" (Alberti, De pictura, in Opere volgari, 3.10). English translation: "To make clear my exposition in writing this brief commentary on painting, I will take first from the mathematicians those things with which my subject is concerned. When they are understood, I will enlarge on the art of painting from its first principles in nature in so far as I am able" (On Painting, trans. John R. Spencer, 43).

${ }^{2}$ This attitude is very clear in the concluding words of the autobiographical section of Lorenzo Ghiberti's Commentarii: "io, chi avesse avute a ffare figure grandi, fuori de la naturale forma, <ò dato le regole a condurle con perfetta 
misura ... Poche cose si sono fatte d'inportanza nella nostra terra non sieno state disegnate et ordinate di mia mano" (97). The edition is based on MS. II.I.333 of the Biblioteca Nazionale in Florence. (To those who wish to make large figures that go beyond the natural form, I've given the rules for drawing them with perfect measure ... Few important works have been produced in our city that I have not designed and ordered myself.)

${ }^{3}$ On Brunelleschi's perspective panels, see Parronchi’s study. On Brunelleschi's relationship with Florentine humanist culture of the first half of the fifteenth century, see Tanturli's essay.

${ }^{4}$ The studies on the novella, or the editions of the novella, which have a direct relevance to this paper are those by Tartaro, Rochon, Domenico De Robertis and Giuliano Tanturli, Borsellino, Billeri, and Procaccioli. The novella was recently translated into English and included in the volume by Lauro Martines. The quotations from the novella are taken from the editions by Ferrero and Doglio, and by Rochon, in the appendix to his article quoted above, for the vulgate and Palatino 51 versions, respectively. Page references are to the English translation of the novella in the volume by Martines.

${ }^{5}$ The theme of the exchange of identity is, of course, part of the classical tradition. Compare this novella to Plautus's Amphitruo, which seems to be its most direct narrative predecessor.

${ }^{6}$ Pliny, 9.310-311. See Ghiberti's quotation-translation of this passage in his Commentarii: "fu costui [Parrasio] abondante artefice, m'alcuno altro usò la gratia della pictura più superbamente, imperò egli usurpò e sopranomi: chiamava sé abhoclito, e con altre parole si chiamava principe della pictura e diceva l'arte esser in perfectione in lui, e diceva esser nato della radice d'Apolline; e diceva avere dipinto Hercule, in quello modo molte volte dormendo gl'era apparito" (Ghiberti 71).

${ }^{7}$ On this tradition see Lindberg's study on theories of vision.

${ }^{8}$ Michclangelo 419, poem No. 247: "Sleep is dear to me, and being of stone is dearer" ("Caro m'è 'l sonno, e più l'esser di sasso").

${ }^{9}$ See Ghiberti, 3.9.4 (132) and also Roger Bacon, Perspectiva, 1.4.3.

${ }^{10}$ See Alberti, Della famiglia, Libro 3. The following is the extended quotation of this passage (from Opere volgari, 1:176; English translation by Watkins: "Dissi io la masserizia sta in bene adoperare le cose non manco che in conservalle, vero? Adunque io quanto al tempo cerco adoperarlo bene, e studio di perderne mai nulla. Adopero tempo quanto più posso in essercizii lodati; non l'adopero in cose vili, non spendo più tempo alle cose che ivi si richiegga a farle bene. E per non perdere di cosa sì preziosa punto, io pongo in me questa regola: mai mi lascio stare in ozio, fuggo il sonno, né giacio se non vinto dalla stracchezza, ché sozza cosa mi pare senza repugnare cadere e giacere vinto, o, come molti, prima aversi vinti che certatori. Così adunque fo: fuggio il sonno e l'ozio, sempre faccendo qualche cosa. E perché una faccenda non mi confonda l'altra, e a quello modo poi mi truovi averne cominciate parecchie e fornitone niuna, o forse pur in quello modo m'abatta avere solo fatte le piggiori e lasciate adrieto le migliori, sapete voi, figliuoli 
miei, quello che io fo? La mattina, prima, quando io mi levo, così fra me ricolgo in me quanto feci il dì. Ivi, se fui in cosa 'lcuna negligente, alla quale testé possa rimediarvi, subito vi supplisco: e prima voglio perdere il sonno che il tempo, ciò̀ la stagione delle faccende. Il sonno, il mangiare e queste altre simili posso io recuperare domane e satisfarle, ma le stagioni del tempo no" [emphasis mine]. ("Did I not say that thrift consists as much in making good use of things as in preserving them? My plan, therefore, is to make as good use as possible of time, and never to waste any. I use time as much as possible on praiseworthy pursuits. I do not spend my time on base concerns. I spend no more time on anything than is needed to do it well. And to waste no part of such a precious thing, I have a rule that I always follow: never remain idle, I avoid sleep, and I do not lie down unless overcome by weariness, for it seems disgraceful to me to fall without fighting or to lie beatenin short, like so many people, to take an attitude or defeat sooner than enter the battle. This then is what I do: I avoid sleep and idleness, and I am always doing something. To be sure that one pursuit does not crowd out another, and that I don't find I have started several things but completed none, or perhaps have done only the less important and left the best undone, do you know, my children, what I do? First thing in the morning, when I arise, I think to myself, "What are the things I have to do today?' ... Then, if I was careless in performing some tasks, and can repair the damage immediately, I do so; for I would sooner lose sleep than lose time, that is, than let the right moment for doing something slip by. Sleep, food, and things of that sort I can catch up on tomorrow, and take care of my needs, but the moment for doing something that must be done, no"(171-172 [emphasis mine]).

${ }^{1}$ See Ghiberti, 1.1.1 (45). The passage, moreover, is taken from Athenaios (see the index of sources in the edition of Ghiberti's Commentarii).

${ }^{12}$ See Vasari, Le vite, 1:283. English translation: The Lives of the Artists, 117. 13 Ibid., 241 (translation 83).

\section{WORKS CITED}

Alberti, Leon Battista On Painting. Trans. John R. Spencer. New Haven and London: Yale University Press, 1966.

. De pictura, in Opere volgari. Ed. Cecil Grayson. Bari: Laterza, 1973. . The Family in Renaissance Florence. Trans. Renée Neu Watkins. Columbia: University of South Carolina Press, 1969.

Bacon, Roger. Roger Bacon and the Origins of Perspectiva in the Middle Ages: A Critical Edition and English Translation. Ed. and trans. David C. Lindberg. Oxford: Clarendon Press and New York: Oxford University Press, 1996.

Billeri, Gabriella. L'esecuzione narrativa. Significazione nella Novella del Grasso legnaiuolo. Rome: Bulzoni, 1984.

Borsellino, Nino "L'architetto e il legnaiuolo. La prospettiva incrociata nella 'Novella del Grasso',' in Miscellanea di studi in onore di Vittore Branca, 3: Umanesimo e Rinascimento a Firenze e Venezia. Florence: Olschki, 1983, Tome 2. 283-295. 
Ghiberti, Lorenzo. I commentarii. Ed. Lorenzo Bartoli. Florence: Giunti, 1998. La novella del Grasso legnaiuolo. Ed. Antonio Lanza. Florence: Vallecchi, 1989 (together with the Geta and Birria story).

. Ed. Paolo Procaccioli. Parma: Guanda, 1990.

in Novelle del Quattrocento. Ed. Giuseppe G. Ferrero and Maria Luisa Doglio. Turin: UTET, 1975.

Lindberg, David C. Theories of Vision from al Kindi to Kepler. Chicago: Chicago University Press, 1976.

Manetti, Antonio. Vita di Ser Brunelleschi preceduta da La novella del Grasso. Ed. Domenico De Robertis and Giuliano Tanturli. Milan: il Polifilo, 1976.

Martines, Lauro. An Italian Renaissance Sextet: Six Tales in Historical Context. New York: Marsilio, 1994.

Michelangelo. The Poetry of Michelangelo: An Annotated Translation. Ed. James M. Saslow. New Haven and London: Yale University Press, 1991.

Parronchi, Alessandro. "Le due tavole prospettiche del Brunelleschi," in Studi sulla dolce prospettiva. Milan: Martelli, 1964. 226-295.

Pliny, Natural History. Ed. Harris Rackham. Cambridge: Harvard University Press, 1952.

Rochon, André. "Une date importante dans l'histoire de la beffa: la Nouvelle du Grasso Legnaiuolo," in Formes et significations de la 'beffa' dans la littérature italienne de la Renaissance. Ed. André Rochon. Paris: Université de la Sorbonne Nouvelle, 1975. 211-376.

Tanturli, Giuliano. "Rapporti del Brunelleschi con gli ambienti letterari fiorentini," in Filippo Brunelleschi. La sua opera e il suo tempo. Florence: Centro Di, 1980, 1:125144.

Tartaro, Achille. "La letteratura volgare in Toscana," in Il Quattrocento, Vol. 2, Tome 1 of La letteratura italiana. Storia e testi. Ed. Carlo Muscetta. Bari: Laterza, 1971. 219-225.

Vasari, Giorgio. Le vite. Ed. Luciano Bellosi and Aldo Rossi. Turin: Einaudi, 1986. The Lives of the Artists. Trans. Julia Conaway Bondanella and Peter Bondanella. Oxford and New York: Oxford University Press, 1991. 